\title{
RELATIONSHIP BETWEEN SOCIAL DEPRIVATION AND ASPECTS OF PSYCHOMOTOR PERFORMANCE IN MIDDLE ADOLESCENCE
}

\author{
C. MURRAY
}

Centre for Youth Studies and Research, Faculty of Education, Manchester University

Though the depressed physical and nutritional status of the deprived groups in our society is historically well documented from both the imaginative (Dickens, 1854) and journalistic (Chadwick 1842) points of view, very few investigations of a scientific nature have been conducted in this area which include objective motor performance measures in their design; the bulk of the available research literature is concerned with socio-occupational or regional differences as related to body size, particularly with regard to difference in height and weight (Meredith, 1951; Clements and Pickett, 1952, 1954; Scottish Council for Research in Education, 1953; Clements, 1953). It is the intention of this paper to call attention to aspects of the psychomotor condition of impoverished children by considering whether a socially determined standard of nutritive deficiency is significantly related to aspects of this condition in addition to the characteristics of height and weight. As a subsidiary we are interested in assessing the differential contribution, if any, of these 'physical' variables to this relationship before and after certain 'environmental' variables are held constant.

While it is true that poverty, reproductive failure, and inadequate nutrition are components of a synergistic interaction, each being mutually reinforcing elements in a complex network of influences associated with the 'disadvantaged', their adverse effects on physical growth and development are probably greatest when such growth would normally be maximal. Consequently one of the most productive periods for assessing whether a socially determined standard of nutritive deficiency is significantly

related to the physical/motor characteristics of the individual is that stage of the development cycle, termed middle adolescence, wherein occurs the adolescent growth spurt (Tanner, 1962).

\section{Methods}

\section{SAMPLE AND HYPOTHESIS}

The data which are analysed and reported here are extracted from a cross-sectional investigation involving cognitive, psychomotor, and social characteristics of adolescents who comprise the complete male third-year groups of 12 secondary modern schools chosen for geographical spread and variation in size and composition. A report of the relationship between cognitive and selected social variables has been published previously and the part sample used for that analysis has been described (Murray, 1971). The distribution of the full sample, for which we have complete psychomotor data, is given in Table I.

Headmasters in each school, having been assured of complete confidentiality, provided the names of those children in the sample who were eligible for free school meals. In this respect eligibility is secured by the Local Education Authority applying remission arrangements consonant with regulations laid down by the Department of Education and Science which indicate that all children of school age who have a parent in receipt of supplementary benefit or family income supplement are entitled to school meals free of charge. Eligibility of children whose parents are not in receipt of this welfare benefit is assessed in accordance with an income

Table I

DISTRIBUTION OF MALE ADOLESCENTS PROVIDING COMPLETE PSYCHOMOTOR DATA, BY CITY AND SCHOOL

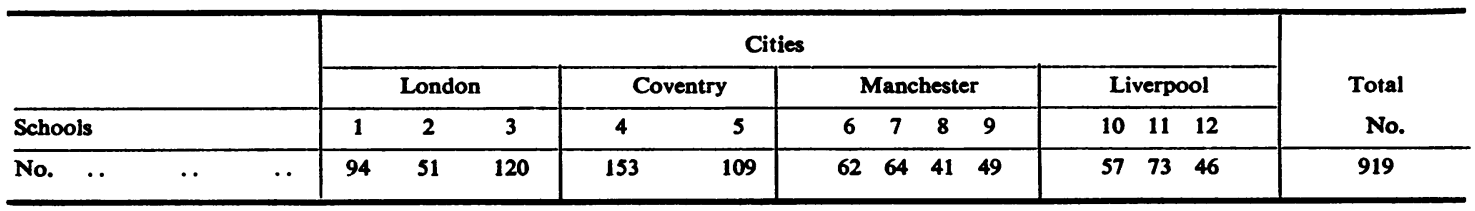


table which indicates the number of children entitled to free meals in a family with a given number of dependent children and a given net weekly income. Thus children who are eligible for free meals are being reared in a situation which is considered by the authorities to be below a minimum subsistence level and these children were labelled, merely for research convenience, as the deprived group $(\mathrm{N}=62)$, the remainder of the sample, again for convenience sake, being termed the "nondeprived' group $(\mathrm{N}=857)$. The headteachers who supplied the classifying information were confident that those children in our sample who were entitled to free meals were so identified. However, it may be the case that a number of children have been wrongly placed in the non-deprived group, this being the likely direction of error. In this case misclassification would result in the data providing a more stringent test of our hypothesis which is cast in a generalized multi-variate null form, viz., that the two groups are similar in height, weight, and psychomotor performance.

\section{MeAsures}

Considerable progress has been made in recent years in identifying and describing, in a statistical sense, the general area of psychomotor performance (Guilford, 1958; Fleishman, 1964). The 20 plus abilities which constitute a general classification of this motor domain include a motor-strength sub-set which has considerable factorial stability across varying samples. Three orthogonal dimensions of this sub-set which have been consistently identified but which have been variously named, depending on the predilections of the investigator, relate to tests which involve the repeated movement or support of the body over a given period of time, the continual exertion of maximum force for a brief period of time, and the mobilization of maximum energy in one explosive act; we follow Fleishman (1964) in describing these dimensions as dynamic, static, and explosive strength. A battery of tests reflecting this taxonomy was used by Fleishman (1964) in his study of the fitness levels of 20,000 boys and girls in schools throughout the United States of America, and a number of these were selected for use in this study in addition to others chosen to provide more complete coverage. Table II gives a brief description of each measure, together with factor loadings and reliabilities, where indicated, derived from the original study.

\section{Procedure}

The tests were administered to all boys in the third year of each school by the author and a trained team
TABLE II

DESCRIPTION OF PSYCHOMOTOR MEASLIRES USED IN THE INVESTIGATION

\begin{tabular}{|c|c|c|c|}
\hline Source & & $\begin{array}{c}\text { Factor } \\
\text { Loading }\end{array}$ & $\begin{array}{l}\text { Test-retest } \\
\text { Reliability }\end{array}$ \\
\hline $\begin{array}{l}\text { Derived } \\
\text { from } \\
\text { Fleishman's } \\
\text { battery }\end{array}$ & $\begin{array}{c}\text { Factor } 1 \text { Dynamic Strength } \\
1 \text { Number of pull ups on } \\
\text { rings suspended from a } \\
\text { horizontal beam to } \\
\text { limit } \\
2 \text { Number of push ups in } \\
15 \text { sec } \\
3 \text { u m b e of s q u a t } \\
\text { thrusts in } 30 \text { sec } \\
\text { Factor } 2 \text { Static Strength } \\
4 \text { Hand grip as registered } \\
\text { in pounds on a dyna- } \\
\text { mometer . } \\
\text { Factor } 3 \text { Explosive Strength } \\
5 \text { Standing broad jump } \\
\text { (distance in inches) . } \\
6 \text { Softball throw } \\
7 \text { distance in feet) } \\
7 \text { Number of sit ups in } \\
30 \text { sec . }\end{array}$ & $\begin{array}{l}0.72 \\
0.66 \\
0.54 \\
0.33\end{array}$ & $\begin{array}{l}0.91 \\
0.93 \\
0.90 \\
0.72\end{array}$ \\
\hline $\begin{array}{l}\text { Supplementary } \\
\text { tests used } \\
\text { to give more } \\
\text { complete } \\
\text { coverage }\end{array}$ & \multicolumn{3}{|c|}{$\begin{array}{l}8 \text { Lateral pull on a dynomometer (lb) (related } \\
\text { to the static strength factor) } \\
9 \text { Number of leg lifts in } 30 \text { sec (this test had } \\
\text { loadings of } 0 \cdot 47 \text { on a trunk factor which } \\
\text { separated out in Fleishman's analysis and } 0 \cdot 32 \\
\text { on the dynamic strength factor; the reliability } \\
\text { coefficient is reported as being } 0 \cdot 84 \text { ) } \\
10 \text { Time on a } 600 \text { yard run (included as : } \\
\text { measure of cardiorespiratory endurance) }\end{array}$} \\
\hline
\end{tabular}

of testers (second-year physical education students) with the exception of the 'softball throw' and ' 600 yd run' which, because of time and situational requirements, were administered by a member of the school's physical education staff. As a check on this procedure 69 boys were chosen at random from one of the larger schools and re-tested on these two tests by the author; the resulting reliability/objectivity coefficients obtained for both measures over the two testing occasions (separated by a three-week interval) were 0.87 and 0.86 respectively, which were considered acceptable for the purposes of this study. In addition to the 10 motor strength measures described in Table II the height of each subject was measured to the nearest 0.5 inch using a stadiometer and weight to the nearest pound using the same set of portable scales, subjects wearing only gym shorts for these measurements.

Prior to analysis, the motor strength measures were converted from raw scores to $T$ scores with a mean of 50 and standard deviation of 10 and prepared for computations together with the incomplete data on subject's measured intelligence (Heim, 1967), social status (Hall and Jones, 1950), and family size.

\section{RESULTS}

The dependent variables for analysis are 10 motor performance measures and two physical characteristics which are hypothesized as being related 
TABLE III

RESULTS OF MULTIVARIATE ANALYSIS OF VARIANCE FOR ADOLESCENTS CLASSIFIED WITH RESPECT TO SOCIAL DEPRIVATION

\begin{tabular}{c|c|c|c}
\hline Component & $\begin{array}{c}\text { Approx. F } \\
\text { df 12,906 }\end{array}$ & $\begin{array}{c}\text { Approx. } \chi^{2} \\
\text { df 12 }\end{array}$ & $\begin{array}{c}\text { Wilk's } \\
\text { Lambda } \\
\text { df 12,917 }\end{array}$ \\
\hline Between group & 3.85 P $<0.001$ & $45 \cdot 33 \quad P<0.001$ & 0.9515 \\
\hline
\end{tabular}

to membership in the two groups as classified and previously described. In this situation analysis is facilitated by use of a general linear model which describes the 12 dependent variables as a vector variable and thus provides a multivariate test for the significance of group separation; in the two group situation, without considering possible covariates, this amounts to a discriminant analysis but the term 'analysis of variance' is preferred as a heading for the tables. The multivariate test of significance, Wilk's Lambda, related to our hypothesis together with its approximate derivatives, is given in Table III.

As the multivariate test statistic is highly significant - the chance of producing group differences this large or larger by drawing two random samples from a 12-dimensional multivariate swarm is less than 1 in 1,000 -we may suggest that the null hypothesis as posed is untenable. We thus proceed to the next stage of the analysis which involves an examination of the descriptive statistics associated with the multivariate test, viz. (1) the means and standard deviations (Table IV) and (2) the scaled canonical variate coefficients and univariate $F$ ratios (Table V).

Inspection of the canonical variate loadings and univariate $F$ ratios in Table $V$ suggests that the variables making most contribution to group separation are variables $1,3,5,7$, and 9 with some slight additional support from variables 2 and 10 . The signs accompanying the loadings together with
TABLE IV MEANS AND STANDARD DEVIATIONS OF HEIGHT, WEIGHT, AND 10 PSYCHOMOTOR VARIABLES FOR ADOL-
ESCENTS CLASSIFIED WITH RESPECT TO SOCIAL
DEPRIVATION

\begin{tabular}{|c|c|c|c|c|c|}
\hline \multirow{2}{*}{\multicolumn{2}{|c|}{$\begin{array}{l}\text { Dependent } \\
\text { Variables }\end{array}$}} & \multicolumn{2}{|c|}{$\begin{array}{l}\text { 'Deprived' Group } \\
(N=62)\end{array}$} & \multicolumn{2}{|c|}{$\begin{array}{c}\text { ‘Non-deprived' Group } \\
(\mathbf{N}=\mathbf{8 5 7})\end{array}$} \\
\hline & & Means & $\sigma$ & Means & $\sigma$ \\
\hline $\begin{array}{l}1 \text { Height } \\
2 \text { Weight } \\
3 \text { Pull ups } \\
4 \text { Push ups } \\
5 \text { Squat thrusts } \\
6 \text { Leg lifts } \\
7 \text { Grip strength } \\
8 \text { Dynamometer }\end{array}$ & $\begin{array}{l}\cdots \\
\cdots \\
\cdots \\
\cdots\end{array}$ & $\begin{array}{r}61 \cdot 55 \\
102 \cdot 39 \\
53 \cdot 22 \\
53 \cdot 32 \\
48 \cdot 00 \\
52 \cdot 63 \\
47 \cdot 32\end{array}$ & $\begin{array}{r}3 \cdot 67 \\
19 \cdot 18 \\
13 \cdot 22 \\
9 \cdot 16 \\
11 \cdot 59 \\
11 \cdot 1- \\
9 \cdot 06\end{array}$ & $\begin{array}{r}63 \cdot 17 \\
107 \cdot 33 \\
46 \cdot 97 \\
51 \cdot 78 \\
51 \cdot 23 \\
51 \cdot 17 \\
49 \cdot 93\end{array}$ & $\begin{array}{r}3 \cdot 32 \\
19 \cdot 78 \\
14 \cdot 66 \\
9 \cdot 97 \\
9 \cdot 70 \\
10 \cdot 02 \\
9 \cdot 79\end{array}$ \\
\hline $\begin{array}{l}\text { pull } \\
9 \text { Broad jump } \\
10 \text { Softball throw } \\
11 \text { Sit ups } \\
12600 \text { yd run }\end{array}$ & $\begin{array}{l}\cdots \\
\cdots \\
\cdots\end{array}$ & $\begin{array}{l}49 \cdot 47 \\
47 \cdot 61 \\
47 \cdot 68 \\
50 \cdot 37 \\
49 \cdot 37\end{array}$ & $\begin{array}{r}9 \cdot 18 \\
11 \cdot 43 \\
10 \cdot 19 \\
10 \cdot 37 \\
10 \cdot 42\end{array}$ & $\begin{array}{l}49 \cdot 80 \\
50 \cdot 94 \\
49 \cdot 91 \\
51 \cdot 30 \\
50 \cdot 54\end{array}$ & $\begin{array}{r}9 \cdot 50 \\
9 \cdot 67 \\
9 \cdot 84 \\
10 \cdot 07 \\
9 \cdot 95\end{array}$ \\
\hline Age (months)* & $\ldots$ & $169 \cdot 22$ & $4 \cdot 62$ & $169 \cdot 72$ & $4 \cdot 01$ \\
\hline
\end{tabular}

*The groups are fortuitiously balanced in this respect.

an inspection of mean differences indicate that the 'deprived group' are shorter and somewhat lighter and have lower motor performance scores, as measured by squat thrusts, broad jump, and grip strength, than the 'non-deprived group'; they score higher, however, on pull ups.

Our introductory comment suggested that social deprivation is a composite of various influences and consequently we now carry the analysis further by removing from it those variables, other than minimum income level, which might be thought largely to account for the discrepancy in performance as noted, family size, social status, and measured intelligence. Initially we test our assumption that the groups will differ significantly with respect to these three variables and run the same analysis as that previously described, this time with family size, social status, and IQ as a vector dependent variable for those cases with complete data $(\mathrm{N}=753)$. The results are shown in Table VI.

TABle V

CANONICAL VARIATES AND UNIVARIATE F RATIOS RELATING TO VARIABLES OF THE MULTIVARIATE ANALYSIS FOR ADOLESCENTS CLASSIFIED WITH RESPECT TO SOCIAL DEPRIVATION

\begin{tabular}{|c|c|c|c|c|c|c|c|c|}
\hline \multicolumn{4}{|c|}{ Dependent Variables } & $\begin{array}{l}\text { Canonical } \\
\text { Variates }\end{array}$ & $\begin{array}{l}\text { Variate } \\
\text { Loadings }\end{array}$ & $\begin{array}{l}\text { Sums of } \\
\text { Squares }\end{array}$ & $\underset{\text { Ratios }}{\mathbf{F}}$ & $\begin{array}{c}\text { Significance } \\
\text { Levels }\end{array}$ \\
\hline $\begin{array}{r}1 \\
2 \\
3 \\
4 \\
5 \\
6 \\
7 \\
8 \\
9 \\
10 \\
11 \\
12\end{array}$ & $\begin{array}{l}\text { Height } \\
\text { Weight } \\
\text { Pull ups } \\
\text { Push ups } \\
\text { Squat thrusts } \\
\text { Leg lifts } \\
\text { Grip strength } \\
\text { Dynamometer } \\
\text { Broad jump } \\
\text { Softball throw } \\
\text { Sit ups } \\
600 \text { yd run }\end{array}$ & $\begin{array}{l}\ldots \\
\ldots \\
\ldots \\
\ldots \\
\ldots \\
\ldots \\
\ldots \\
\ldots\end{array}$ & $\begin{array}{l}\cdots \\
\cdots \\
\cdots \\
\cdots \\
\cdots \\
\cdots \\
\cdots \\
\cdots\end{array}$ & $\begin{array}{r}-0.8722 \\
0.0441 \\
0.2667 \\
0.0471 \\
-0.2481 \\
0.0507 \\
-0.0589 \\
0.1557 \\
-0.2484 \\
-0.0522 \\
-0.0826 \\
0.0286\end{array}$ & $\begin{array}{r}-0.5386 \\
-0.2784 \\
0.4763 \\
0.1730 \\
-0.3650 \\
0.1598 \\
-0.2977 \\
-0.0395 \\
-0.3773 \\
-0.2512 \\
-0.1026 \\
-0.1297\end{array}$ & $\begin{array}{r}152 \cdot 39 \\
1415 \cdot 40 \\
2257 \cdot 86 \\
138 \cdot 09 \\
605 \cdot 33 \\
122 \cdot 04 \\
394 \cdot 48 \\
6 \cdot 58 \\
641 \cdot 09 \\
288 \cdot 22 \\
50 \cdot 39 \\
78 \cdot 58\end{array}$ & $\begin{array}{r}13 \cdot 57 \\
3 \cdot 62 \\
10 \cdot 61 \\
1 \cdot 40 \\
6 \cdot 23 \\
1 \cdot 19 \\
4 \cdot 15 \\
0 \cdot 07 \\
6 \cdot 66 \\
2 \cdot 95 \\
0 \cdot 49 \\
0 \cdot 79\end{array}$ & $\begin{array}{l}0.01 \\
\text { NS } \\
0 \cdot 01 \\
\text { NS } \\
0 \cdot 05 \\
\text { NS } \\
0 \cdot 05 \\
\text { NS } \\
0 \cdot 01 \\
\text { NS } \\
\text { NS } \\
\text { NS }\end{array}$ \\
\hline
\end{tabular}


TABLE VI

MULTIVARIATE ANALYSIS OF VARIANCE FOR ADOLESCENTS CLASSIFIED WITH RESPECT TO SOCIAL DEPRIVATION: FAMILY SIZE, SOCIAL STATUS, AND MEASURED INTELLIGENCE ARE DEPENDENTS

\begin{tabular}{l|c|c|c}
\hline Component & $\begin{array}{c}\text { Approx. F } \\
\text { df } 3,749\end{array}$ & $\begin{array}{c}\text { Approx. } \chi^{2} \\
\text { df } 3\end{array}$ & $\begin{array}{c}\text { Wilk's } \\
\text { Lambda } \\
\text { df 3,751 }\end{array}$ \\
\hline Between groups & $10.61 \quad P<0.001$ & $31 \cdot 18$ P $<0.001$ & 0.9592 \\
\hline
\end{tabular}

As expected, our assumption holds good, the result of the analysis being highly significant, and from the point of view of interest rather than relevance we may note that family size makes the greatest contribution to between group separation (univariate $F=24 \cdot 13$ ) followed by measured intelligence (univariate $F=10.61$ ) and social status (univariate $F=$ $7 \cdot 42$ ). We now re-run the original analysis with these three variables introduced into the model as covariates thus statistically removing their influence from between group discrimination. Table VII shows the results.

TABLE VII

MULTIVARIATE COVARIANCE ANALYSIS, TOGETHER WITH DESCRIPTIVE STATISTICS OF HEIGHT, WEIGHT, AND PSYCHOMOTOR VARIABLES FOR ADOLLESCENTS CLASSIFIED WITH REGARD TO SOCIAL DEPRIVATION

\begin{tabular}{l|cc|c|c}
\hline Component & $\begin{array}{c}\text { Approx. F } \\
\text { df 12,737 }\end{array}$ & \multicolumn{1}{|c|}{$\begin{array}{c}\text { Approx. } x^{2} \\
\text { df 12 }\end{array}$} & $\begin{array}{c}\text { Wilk's } \\
\text { Lambda } \\
\text { df 12,748 }\end{array}$ \\
\hline Between groups & 2.57 & P $<0.01$ & $30.43 \quad$ P $<0.01$ & 0.9598 \\
\hline
\end{tabular}

RELATED DESCRIPTIVE STATISTICS:

\begin{tabular}{|c|c|c|c|c|}
\hline Dependent Variables & & $\begin{array}{l}\text { Canonical } \\
\text { Loadings }\end{array}$ & $\underset{\text { Ratios }}{\mathbf{F}}$ & $\begin{array}{c}\text { Signifi- } \\
\text { cance }\end{array}$ \\
\hline 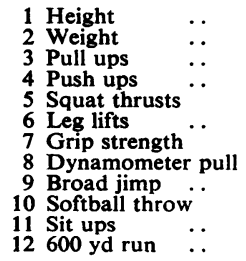 & $\begin{array}{l}\ldots \\
\cdots \\
\cdots \\
\cdots \\
\cdots \\
\cdots \\
\cdots \\
\cdots \\
\cdots\end{array}$ & $\begin{array}{r}-0.3888 \\
-0.0307 \\
0.3109 \\
0.0731 \\
-0.5707 \\
0.1064 \\
-0.2323 \\
0.1401 \\
-0.2010 \\
-0.1230 \\
-0.0345 \\
-0.0009\end{array}$ & $\begin{array}{r}4 \cdot 73 \\
0 \cdot 03 \\
3 \cdot 03 \\
0 \cdot 17 \\
10 \cdot 20 \\
0 \cdot 35 \\
1.70 \\
0 \cdot 61 \\
1 \cdot 26 \\
0 \cdot 47 \\
0 \cdot 04 \\
0 \cdot 00\end{array}$ & $\begin{array}{l}<0 \cdot 05 \\
\text { NS } \\
\text { NS } \\
\text { NS } \\
<0 \cdot 01 \\
\text { NS } \\
\text { NS } \\
\text { NS } \\
\text { NS } \\
\text { NS } \\
\text { NS } \\
\text { NS }\end{array}$ \\
\hline
\end{tabular}

Observation of the results in Table VII indicates that, although the approximate tests of significance are now reduced in size, when the groups are balanced for age and are equated statistically with respect to measured intelligence and the background variables of social status and family size then the motor performance measures still discriminate between the groups at the 0.01 level. The measures now contributing most to between group separation are height and squat thrusts.

\section{Discussion}

In the non-scientific literature there is frequently expressed the belief that the advent of the welfare state and the gradual improvement in the nutritional and environmental status of schoolchildren has made such supplementary social provision as free school meals and milk unnecessary. There is certainly some evidence that the discrepancy in physical characteristics between socio-economic groups is now less than it was; for example, Clements (1953) interprets the published data relating to the heights and weights of British schoolchildren since the turn of the twentieth century as suggesting that the increase in height and weight of these children for a given age, the well marked secular trend, has been greatest in the lower income groups. He concludes that the end result of this differential gain is that 'average children of the same age in the middle and lower income groups are the same height, while the average child in the upper income group is about 2 inches taller .... weight differences between comparably aged boys of the three income groups have now been eliminated'. From our results we would agree that weight is not an important discriminator between income groups but would suggest that even in a sample which is relatively generally depressed in $\$$ socio-economic sense then those children who are from the lowest income groups are at a disadvantage with respect to their peers, not only in terms of height but also with regard to the motor strength aspects of the psychomotor domain. The one exception to this observation is with regard to the requirement of continual lifting the body by use of the arms only (pull ups), and we may most probably account for the favourable performance of the deprived group on this measure by reference to their shorter stature and lighter body weight, this interpretation being consonant with the known factorial relationship of the three measures. The general relationship, though reduced in magnitude, as observed for our data still holds when possible 'explanatory' influences over and above income level are held constant; as the major discriminating variables in this case are height and squat thrusts, the latter being the only test in the battery requiring some explicit co-ordination, these probably relate to a genetic component of what is a very complex situation (Tanner, 1966).

\section{SUMMARY}

Nine hundred and nineteen male adolescents located in 12 secondary modern schools in four cities provided complete data on age, height, weight, and 10 measures related to the motor 
strength area of the psychomotor domain; incomplete data were also obtained with respect to each individual's measured IQ, social status, and size of family. Those children in the sample who were eligible for free school meals were classified as a 'deprived group' and were found to differ significantly from their peers in motor strength and height, such difference still being maintained when between group differences in IQ, family size, and social status are controlled statistically.

I would like to acknowledge the assistance afforded by my colleague at the University, Professor Alwyn Smith, Head of the Department of Social and Preventive Medicine, who suggested some modifications to the draft typescript of this article.

\section{REFERENCES}

ChADWICK, E. (1842). Report on the Sanitary Conditions of the Labouring Population of Great Britain, (1965 edition edited by $M$. W. Flinn, Edinburgh University Press, Edinburgh).

Clements, E. M. B. (1953). Changes in the mean stature and weight of British children over the past seventy years. Brit. Med. J., 2, 897.

-, and PicketT, K. G. (1952). Stature of Scotsmen aged 18 to 40 years in 1941. Brit. J. prev. soc. Med., 6, 245. and - (1954). Chest girth of men related to stature, age, body-weight, and social status. Brit. $J$. prev. soc. Med., 8, 108.

Dickens, C. (1854). Hard Times. Chapman and Hall, London.

Fleishman, E. A. (1964). Structure and Measurement of Physical Fitness. Prentice Hall, New York.

GUILFORD, J. P. (1958). A system of the psychomotor abilities. Amer. J. Psychol., 71, 164.

HALl, J. and JoNES, D. C. (1950). Social grading of occupations. Brit. J. Sociol., 1, 31.

Heim, A. W. (1967). A.H.4 Group test of General Intelligence, rev. ed. National Foundation for Educational Research, Slough.

Meredith, H.V. (1951). Relation between socio-economic status and body size in boys seven to ten years of age. Amer. J. Dis. Child, 82, 702.

MURRAY, C. (1971). The effects of ordinal position on measured intelligence and peer acceptance in adolescence. Brit. J. soc. clin. Psychol., 10, 221.

SCOTTISH COUNCIL fOR ReSEARCH IN EDUCATION (1953). Social Implications of the 1947 Scottish Mental Survey. University of London Press, London.

TANNER, J. M. (1962). Growth at Adolescence, 2nd ed. Blackwell, Oxford.

(1966). Galtonian eugenics and the study of growth: the relation of body size, intelligence test score, and social circumstances in children and adults. Eugen. Rev., 58, 122. 